\title{
Articulation of Legitimacy: A Theoretical Note on Confrontational and Nonconfrontational Approaches to Protest Policing
}

\author{
Janjira Sombatpoonsiri
}

\begin{abstract}
The Weberian notion of states holding the monopoly on violence can be challenged in the light of states dealing with street protests. In established democracies, the police handling of street protests is characterized by the oscillation between confrontational and nonconfrontational approaches. In the United States, the escalated force approach was common up until the 1980s, while in the UK, the government dealt with urban riots heavy-handedly. In the 1990s the negotiated management approach emerged. This research argues that unraveling this oscillation requires understanding of democratic states' upholding of their legitimacy. Violent crackdown on protests can undermine governments' legitimacy. However, by associating public order violators with threat, democratic states may resort to force against protesters, deriving its legitimacy from the public's paranoid mentality.
\end{abstract}

Keywords street protest, state response, legitimacy, escalated force, negotiated management

\section{Introduction}

The policing of protest mirrors an aspect of the relationship between the state and society. The social contract between the sovereign and the people constitutes the bedrock of modern states. Contractarian theorists believe that if the popular sovereign violates this contract, its legitimacy to govern can be challenged (Arendt 1970; de La Boétie [1552] 1975). The states failure to deliver public goods, or its abuse of power, are conditions perceived to violate the social contract, thereby potentially invoking public anger. This public rage can be expressed in the form of street protest, recently witnessed in Turkey, Ukraine, Thailand, Egypt, Hong Kong, Venezuela and many other places. In this sense, a street protest provides grievance groups a tool for expressing resentment and demonstrating demands to the ruling elites and the general public. This is especially the case when 
conventional channels, such as elections, legislative, and juridical procedures, are exhausted or inaccessible-as pointed out in the vast number of studies of social movements and nonviolent resistance (Sharp 1973; Tilly 1978; Bond 1994; McAdam, McCarthy, and Zald 1996; Zunes et al. 1999; della Porta and Diani 1999; Schock 2005; Chenoweth and Stephan 2011; Nepstad 2011). In a democratic state, peaceful assembly is a right of citizens as part of participatory politics, and the state is responsible for protecting this right.

In contrast to the contractarian perspective, the law and order outlook identifies dissidence against the state as a potential threat posed to public order. And if the state's raison dêtre is to provide its citizens with a certain degree of internal and external security through its centralized deployment of armed force, dealing with such a threat at all costs can be justified. A state's popular legitimacy and credibility can arise from its ability to sustain public order through rigid policing, rather than from its facilitation of public manifestation of grievances. Existing research on state repression typically points out that authoritarian governments and dictatorships are prone to adopt the law and order outlook, resulting in authorization of unrestrained use of force against dissidents (Marx 1979, 94-125; Churchill and Vander 1990; Kowalewski 2003; Sluka 2000; Earl 2003; Davenport 2005, vii-xx). This implies that democratic governments should consistently avoid forceful handling of protesters, principally due to their observance of human rights principles and the existence of political infrastructure governing police accountability.

In Policing Protest: The Control of Mass Demonstrations in Western Democracies (della Porta and Reiter 1998), a seminal work on protest policing, the authors develop a similar argument. Diverging factors shaping state responses to street demonstrations are put forward (such as organizational features of the police, the configuration of political power, public opinion, the police occupational culture, interaction with protesters, and police knowledge). The combination of these factors creates a dichotomized approach to protest policing (e.g., brutal versus soft, illegal versus legal, and confrontational versus consensual) (ibid., 4). However, the explanation of factors underpinning democratic states' oscillation between heavy-handed and tolerant approaches stops short at the institutional level. A question remains unanswered: How does this methodological inconsistency allow us to understand the complex relationship between the state and its legitimacy when contested by street politics? This paper surveys two dominant models of protest policing emerging in the UK and the United States in different periods of social conflict. Based on this survey, it offers theoretical observations as to ways in which the state agents' articulation of legitimacy comes into play in protest policing. 


\section{Two Approaches to Protest Policing}

Two dominant approaches to protest policing are the escalated force or confrontational approach, and the negotiated management or nonconfrontational approach. While dichotomizing approaches to protest policing can be problematic (Vitale 2005), focusing on these two approaches allows us to see the inconsistent shift between these two models looking primarily at the United States and the UK where democratic institutions guarantee the right to freedom of speech and peaceful assembly. The shift between confrontational and nonconfrontational approaches reflect the dynamics of state response to protest instigated by three main factors: lessons learned from past experiences of protest policing, the fast changing nature of social conflict, and police force professionalization.

\section{Escalated Force or Confrontational Approach}

The escalated force model of protest policing is based on the belief that law and order has supremacy over civil liberty, and therefore violent response to protesters is deemed necessary when public order is disrupted. The practice can be traced back to 19th century England where confrontational protest policing was initiated to deal with industrial riots. The ruling elites to some degree accepted riotous protests, understanding their role in allowing the underrepresented masses to communicate their grievances. However, with the advent of industrial capitalism, systematic maintenance of public order was needed in order to stabilize society, and in return help maximize industrial production. Accordingly, "riot came to be regarded... as a fundamental threat to the social and political order" (Hobsbawm 1959, 116; also see Storch 1980, 34). Through the association of wealth with increased power of the state, police force became profoundly instrumental. Not only were they deployed to tackle crime, the bureaucratized police were also commissioned to put down pickets and riots as they were a cause of political and economic instability. In this sense, the development of confrontational protest policing was in line with the central role of the state in providing domestic security. In achieving this, the state proceeds to centralize violent means of control (Weber 2002, 13; see also Kaldor 1998, 21-30). And violent suppression of protesters represents this characteristic of the (capitalized) state when encountering a real or perceived threat to domestic security (Waddington 1987, 38).

The conception of protesters as "crowd" provided discursive ground for the dominance of the confrontational approach to protest policing at least until the 1970s. Influential is Gustav Le Bon's The Crowd: A Study of the Popular Mind, which equates street demonstrators with irrational, emotional, and hysterical "women" (Le Bon [1895] 1960). In addition, the transformation hypothesis is introduced to differentiate between "crowd" and "mob." While crowds can be 
expressive in their subversive acts, crowd members do not always engage in "aggressive" activities or riots. Aggression is, in this sense, the defining behavior that transforms the crowd into a mob, which, according to mob sociology, refers to a group of mindless people at the bottom of society whose dissent is driven by anger. Within this framework, little has been explained about social causes of collective outrage. Mobs are presented as troublemakers disturbing public order. Hence, the state, in fulfilling its fundamental task of security provision, is justified in clamping down on "mobs" (Lohman 1947; Momboisse 1967a; 1967b; 1967c).

Reviewing police manuals, training texts, and magazines is a good way to see how the image of violent mobs - as created by mob sociology-has been reproduced. For example, in 1967 the U.S. Federal Bureau of Investigation (FBI) listed a typology of crowds participating in and/or favoring violence ranging from "impulsive and lawless people," who start the riot and incite others to violence, to "psychopathic individuals" who are just angry at the world. The transformation hypothesis is included in a civil disturbance orientation course (CDOC) developed by the U.S. Army, which forms the content of riot-control training workshops. The workshop curriculum explained that anonymity, suggestibility, emotional contagion, novelty, and imitation constituted psychological factors influencing collective acts that could involve aggression, law violation, and vandalism (cited in Schweingruber 2000, 377). In a similar fashion, several police magazines, such as Police and Law and Order, emphasized the emotional characteristics of "mobs" influenced by socio-psychological factors (Pegg 1968; Looney 1970, 34-35, 82; Cromwell and Lewis 1971, 30-32; Dragnich 1972, 24-29, 35).

The escalated force model adopted the image and discourse of violent mobs and became instrumental in handling the anti-Vietnam war protests and civil rights campaigns in the United States. The notion of "public order management" was initially evoked to tackle "waves of public order disruption" (McPhail, Schweingruber, and McCarthy 1998, 64). The public order system was primarily designed to enable cooperation between civilian, police, and military organizations in dealing with protests. It also served to transmit "crowd control" knowledge along the organizational lines of these security forces. Several manuals and training guidelines were produced, reflecting patterns of the escalated force model. These patterns are (1) the undermining of rights to protest or freedom of expression; (2) low or zero tolerance of any signs of disorder; (3) no communication or negotiation with protesters; (4) the initial presence of force; (5) massive arrests of individuals who violate persons or property, or who engage in nonviolent civil disobedience; and (6) use of force to disperse demonstrators and/ or mete out physical punishment in lieu of arrests (McPhail and McCarthy 2005, 4-5, 53; Schweingruber 2000, 378). Lethal dispersion tactics may be employed including shooting at protesters with live ammunition (Waddington 1994; Schweingruber 2000, 54-55). 


\section{Negotiated Management or Nonconfrontational Approach}

Nonconfrontational protest policing that emerged in early 19th century England and in the United States in the 1980s constituted a politically preferable option for the police in their handling of mass demonstrations. The rise of the civil rights discourse in established democracies and the professionalization of police forces influenced this transformation.

The civil rights discourse, which covers freedom of speech and the right to public assembly, has generally contested mob sociology and its construction of a violent mob image. In the UK, freedom of expression and the right of public assembly are not legalized, but accepted as customary. In the United States, these rights are expressed in the First Amendment to the Constitution. In France, they have been manifested in law. In Canada, the Charter of Rights and Freedoms provides for the fundamental freedoms of thought, belief, opinion and expression, freedom of peaceful assembly, and freedom of association. Although this right is at times in tension with public order laws-as in the case of Canada where the Peace, Order and Good Government clause of the Constitution Act of 1867 mandates against protest groups-the right to public assembly has become a reference point for protesters to legitimize their street politics. Security forces, for instance, are held accountable when nonviolent protests are violently suppressed (della Porta and Reiter 1998, 10-11).

In addition, the availability of social movement research and globalized norms based on the human rights discourse help humanize the "crowd." Resource and mobilization theory, emerging from Social Movement Studies, offers an insight into ways in which state challengers are rational and schematic in the formulation of their goals, plans, and protest repertoires. They are thinking agents rather than an irrational and faceless crowd (McAdam, McCarthy, and Zald 1996, 4-5). This line of thought is the legacy of the European Enlightenment that gave priority to an individual's ability to reason. For liberal thinkers, the collective consent of these individuals enthrones the sovereign. In return, the sovereign is expected to respect and guarantee individual rights. This idea has been translated into the Universal Declaration of Human Rights and the European Convention on Human Rights, both of which include rights to freedom of expression and peaceful assembly. A state's violation of these rights is considered a breach not only of the social contract, but also of an international norm (Donnelly 2009).

The emergence of the negotiated management approach in the United States in the 1980s exemplified the influence of the rights discourse on the changing approach to protest policing. Student protests, civil rights campaigns, and the post-Martin Luther King assassination riots resulted in the founding of three commissions to investigate conflict causes and police practices. These were the National (Kerner) Commission on Civil Disorder, the National (Eisenhower) Commission on the Causes and Prevention of Violence, and the National (Scranton) Commission on Campus Unrest. While the Kerner Commission 
specifically addressed ways in which protest policing contributed to popular discontent and recommended eradicating this abusive practice, the Eisenhower Commission offered a broad recommendation that shaped four fundamental components of the negotiated management model. These are (1) the recognition of group protests as a constituent part of national political culture; (2) the acknowledgement of the constitutional right to peaceful assembly; (3) use of coercive tactics as a last resort due to their potential for being counterproductive to constructive conflict resolution; (4) the willingness to negotiate the protest's time, place, and manner, and the granting of permits to protests. The Department of Justice directed the United States Army Military Police School (USAMPS), which offered a civil disturbance orientation course, to substitute the escalated force model in the new approach. The main reason was that "traditional policing actions risked provoking more disorder rather than its resolution" (McPhail, Schweingruber, and McCarthy 1998, 55-56).

Meanwhile, federal court decisions between 1960 and 1995 provided fertile ground for applying the First Amendment in ways that restricted the police from outlawing certain types of direct action by protesters. The ruling of Chicago $v$. Mosely (1972), for instance, confirmed that the "First Amendment means that the government has no right to restrict expression because of its message, its ideas, its subject matter, or its content," regardless of how provocative and offensive those may be. In later court cases these rights would cover the protection of civil rights marchers from hostile onlookers (King Movement Coalition v. Chicago, 1976), the protection of far right demonstrators from counterdemonstrators (Skokie v. National Socialist Party, 1978), and the protection of the right to burn the U.S. flag (United States v. Eichmann, 1972) (Gora et al. 1991). During this period the courts had the major role in the evolution of the protest permit system, which restricts the time, place, and manner of protest. Although criticized for formalizing street demonstrations through registration procedures that entail complicated paperwork, this system generally allows agreements to be made between authorities and protesters prior to actual demonstrations so as to preclude unexpected incidents (McPhail, Schweingruber, and McCarthy 1998, 75).

Moreover, professionalization of the police force helps demilitarize protest policing. In the early 19th century England was hit by waves of industrial disputes and strikes. These were traditionally responded to with a military or militia crackdown, which often ended in deepening popular resentment against the state. Moreover, because soldiers were also recruited from among the poor, they could be politically unreliable in dealing with collective protest (Stevenson 1977, 33-34). In 1829 the London Metropolitan Police was established to institutionalize police practices in the face of urban protests. The main architects in revising British protest policing (including Home Secretary Sir Robert Peel and the first two Metropolitan Police Commissioners, Rowan and Mayne) drew lessons learned 
from past handling of urban protests. They asserted that the police must strive to achieve the support, or at least the acquiescence, of the mass of the population. The police may appear to lose when refusing to use heavy-handed measures in response to riots. However, this can result in a political victory for the police, as the public may show sympathy to them while questioning the legitimacy of violent protests. Public sympathy, in this sense, constitutes "a more powerful weapon than water cannon, tear gas, or plastic bullets" (Reiner 1998, 41). The "winning over" approach remains influential in contemporary British protest policing. For example, a series of negotiations with protest organizers regarding venues, time, and traffic are usually employed. The aim is to dissipate any tension, hostility, or antagonism that the organizers might harbor, and to avoid "trouble" that could undermine the professional reputation of the police (Waddington 1998, 121).

The minimal force strategy stands at the core of non-confrontational protest policing in the UK. Following the 1856 County and Borough Police Act, the police role in preventing crime and public disorder was clearly distinguished from the military role in defending the country from external threats. Identification with citizens and a minimal force image have been central to institutionalized policing: "A police force is essentially civil, unarmed and acting without any assistance from a military force" (Reiner 1998, 42). Police officers were unarmed apart from truncheons on routine patrol, and other weapons (pistols, cutlasses) were restricted to specially selected and trained officers who were issued with them only for especially dangerous assignments (ibid.). With certain exceptions (which will be discussed in the following section), British policing tactics employed during intense standoffs were limited to pushing and shoving. In addition, the police officers were not permitted to dress in riot gear as this might give the impression to bystanders that the police were expecting trouble. This could expose the police to the allegation that any disorder that might arise was the result of a self-fulfilling prophecy (Waddington 1998, 123).

In the United States, the experience gained from responding to civil rights campaigns enabled the replacement of coercive tactics with negotiation techniques, and better collaboration across different security sectors contributed to this shift. Rather than controlling the crowd, metropolitan police are now in charge of managing public disorder. In certain cities, including New York and Washington D.C., this task is delegated to special units. They may be linked to other federal and international police agencies (such as fire agencies, fingerprint and record search services of the FBI, and Interpol) to increase their effectiveness and extensiveness in monitoring protests. Specialized courses, training workshops and seminars in public order policing techniques have also been offered at numerous police academies (McPhail, Schweingruber, and McCarthy 1998, 65-66). Negotiation techniques form the core of these training courses. For instance, it is suggested that the appointment of official liaisons is important for 
maintaining contact with protest organizers. This can create a safe environment during the protest activities such as marches and rallies (Martin 2007, 197). More importantly, some course guidelines covering social and political causes of protests associate the importance of police negotiation with conflict mitigation (Kenny et al. 2001).

Police professionalization encourages the ethic of nonpartisanship in protest policing. The emergence of the British bobby, for instance, corresponded with the institutional separation between the police force and the army. The police were expected to perform a variety of services to people in need, particularly the management of criminal victimization. The image was that of the police as merely "citizens in uniform," paid to carry out civic tasks like other citizens (Reiner 1998, 41). The police were charged to present their image as nonmilitaristic. Meanwhile, in other parts of Europe, demilitarization of protest policing resonated with state modernization in which military force was preserved to defend the country from external threats only. Leaders realized that popular uprisings in the early 19th century resulted from the sovereign's crisis of legitimacy. Handling them with heavy-handed military intervention might exacerbate such crises (Johansen 2008, 71). Similarly, in the early 1970s the role of the U.S. military forces in protest policing was marginalized. While they remained the key provider of public disorder management training sessions, military intervention in actual riot incidents would require presidential authorization (McPhail, Schweingruber, and McCarthy 1998, 67).

Police nonpartisanship manifests on two levels: non-partisanship with regards to the issue and non-partisanship in a role. The former implies police dissociation with a particular position on the issue under protest. And the latter determines their role in minimizing public disturbances, rather than protecting the interests of protesters' target (e.g., the government or private companies). Presumably, achieving this nonpartisan image can increase police legitimacy in the sight of protesters. The outcome may be a change in protesters' perception that associates the police with a threat. This may consequently restrain their provocative acts that in turn invite a police heavy-handed response. When mutual violence between police and protesters is prevented more opportunities are opened for communication between the police and protesters, and this makes possible more constructive interactions resulting from street politics (Waddington 1987, 38; Redekop and Fare 2010, 85-86).

\section{Oscillation between the Two Approaches}

The advent of the negotiated management approach is far from being "The End of History," or the extent of possible progress towards unarmed responses to protesters on the part of states. Countries adopting this approach show a 
history of "opting out" when facing high-key threats to sovereignty and national security. The UK is a prime example here. The British minimal force strategy was undermined by the late 1960s and early 1970's anti-war and student protests that "got out of control." The failure of the police to restore public order, or even to defend themselves from the vandalizing protesters, convinced the authorities to toughen their protest policing strategies. More importantly, British public opinion apparently supported harsher police measures that were seen as needed to safeguard their security (Reiter 1998, 44-47). Paramilitary units for crowd control emerged in this context. They were characterized by militarized and hierarchical organization, and personnel's deployment of riot control weapons. In terms of relationship with protesters, professional riot squads had little identification with the community. Social distance between protesters and the security forces increases the possibility of violent suppression (Jefferson 1987; 1990; Waddington 1987, 37-46).

In the United States, the $9 / 11$ attacks set the stage for prioritization of national security and public order over civil rights. Notorious were the enactment of the Patriot Act and establishment of the Department of Homeland Security, steps that enhanced police authority for surveillance and intelligence gathering. In countering social movements, the police can now gather activists' private information as well as protest tactics through the protest registration system, infiltration of the movements, and surveying open source information. Audiovisual technology is installed in and around cities to help the police identify those breaking the law (della Porta 2006, 176). The impact of these tactics ranges from minor disruptions of a protest event, to obstructing protesters from inducing any political leverage, to emasculating the entire movement (Mitchell and Staeheli 2005; Fernandez 2008).

Under the Patriot Act, the new category of "domestic terrorism" was created, helping cultivate the perception among security forces that street demonstrations could compromise order and security. This led to the creation of a paranoid atmosphere, discouraging general sympathizers with protest causes from participating in demonstrations. For instance, in 2003, when the New York peace activists submitted a request to march through New York City, the federal government filed a brief with the federal court suggesting the court give substantial weight to security concerns in the post-9/11 environment. And a few days prior to the protest the federal government changed the national terrorism alert to the higher "orange" level. When protests were allowed, they were restricted to areas with difficult access or far from the city center (Vitale 2005).

In addition, protest events have been controlled through tactics of micromanagement, undermining the political impact of protest events. For instance, the Miami City Commission and New York Police Department prohibited anti-globalization activists from wearing masks that have been the movement's symbol of solidarity. Moreover, following the protest permit system 
often forces protest organizers to camp far from the city centers where they can better attract attention of pedestrians. Also, when carried out frequently, the stop-and-search tactic can discourage many potential participants from entering the site, and prevent the return of protesters who visit their homes (Swain 2013; see also Fernandez 2008, 102-116; International Network of Civil Liberties Organizations 2013).

Opting out of the negotiated management approach, the police became highly militarized even when dealing with peaceful demonstrations. With the technological development of less lethal weapons (LLWs), evidence of a bloody crackdown became virtually invisible, and thereby the police (and the government) could avoid backlashes from repression. LLWs are designed to create a physical distance between police and protesters, immobilize individual protesters, and induce protesters to retreat. In general, there are four types of LLWs, the effects of which vary: kinetic energy projectiles, acoustic weapons, active denial systems, and chemical riot control agents. For instance, electric shock weapons (TASERs) use electromuscular disruption to override the central nervous system and trigger uncontrollable contraction of the muscle tissue. Chemical riot-control agents (e.g., pepper spray or tear gas) act peripherally to produce local sensory irritant effects on the eyes, mucous membranes, and skin (Gobinet 2011, 90).

Despite their label that promises minimization of fatal injury, LLWs can "inflict serious or lethal injury to the target" if misused or used without training (Small Arms Survey 2011). For instance, baton rounds can induce significant injury when utilized to immobilize people. Similarly, pepper spray and TASER guns can produce negative bodily reactions (Redekop and Fare 2010, 66). The active denial system projects a focused beam of electromagnetic radiation to heat the skin of its target to 130 degrees, creating an intolerable burning sensation, forcing protesters to instinctively flee the area. Developed by the American Technology Corporation, the long-range acoustic device can permanently damage hearing by broadcasting sound over ranges of up to hundreds of yards (Khalek 2011). In a broader context where LLWs are used for both public disorder management and crime control, existing studies show that these weapons tend to cause "unnecessary injuries to and deaths of civilians" (MacDonald, Kaminski, and Smith 2009). According to Amnesty International, in the U.S. alone there were approximately 351 TASER-related deaths between 2001 and 2008, and in 2010 the number of deaths reached 390 (Amnesty International 2008; 2012). The LLWs and militarized police are now at odds with civil society at a time when economic and social crises are motivating the worst-off and socially marginalized to take to the streets (Parton 2011; Wolf 2012; ICLO 2013, 4-9; Nocella and Gabbard 2013). Instead of resolving crises, the turn by the United States to the escalated force approach for policing protest has weakened the country's democratic spirit (della Porta 2013, 124-149). 


\section{Making Sense of the Oscillation between Armed and Unarmed Protest Policing}

Based on this survey of state response to street protest, two theoretical observations arise. The first observation regards the state's necessary monopoly of violence. The state's fundamental task to guarantee public safety should be contextualized in 16th and 17th century Europe where the Hobbesian state of nature manifested in the high rate of homicide. However, this changed after the established states had set up police forces and judicial bodies, criminalizing homicide and punishing violators (Weber 2002; Pinker 2011, 79-85). In exchange for mitigating threats in the public realm, the state was now licensed to be the only legitimate user of violence. As discussed earlier, street protesters may cause disruption of public order, and so law defenders, especially the police, feel obliged to protect this order at all cost. The emergence of the negotiated management or nonconfrontational approach, nevertheless, shows us the change in this pattern. Varying factors are responsible for this shift such as the type of regime, the legal code regarding rights and order, and police organizational culture and knowledge (della Porta and Reiter 1998). But beyond institutional factors, there lies the politics of legitimacy shaping the state agent's decision to opt for, or bypass, the use of force in countering protesters.

As a representative of a government and the state, the legitimacy of the police is based on popular perception of their credibility (Rosanvallon 2011, 171186; Tyler 2004). A protest campaign may be launched to publicize grievances inflicted on groups by, for instance, the incumbent government. The campaign may aim to create a crisis of legitimacy for the current government in an attempt to negotiate for policy changes or, in some cases, instigate a change of government. In this legitimacy contestation, the government's political survival depends on the extent of popular support it receives. Violent crackdown on a peaceful demonstration may undermine this base, deepening the crisis of legitimacy and facilitating achievement of the protest group's goal (Sharp 1973, 117-119; Martin 2007; Chenoweth and Stephan 2010, 46-55; Nepstad 2011). In the politics of legitimacy, the state's suppression of street protesters can imply the loss of political momentum (Janjira 2013; 2014). The police and other state apparatus, such as those in England in the early 19th century and in the United States in the 1970s, learned this lesson from their past experiences of violent crackdown, which largely underpinned the institutional re-engineering that gave rise to nonconfrontational approaches to protest policing (Reiner 1998; Waddington 1998).

Meanwhile, the development of the civil rights discourse became instrumental in "civilizing" the state's behavior in such a way that the state's violation of such rights can cost it a bad name domestically and internationally, and so militate 
against any prospective violation. When scenes of violent clampdowns on civil rights activists in the United States was televised globally, the U.S. government was pressured to set up an investigatory commission which eventually concluded that the excessive use of police force was unconstitutional and incongruent with democratic principles. The commission suggested that minimal force and problem-oriented approaches should be the pathway to conflict resolution. In sum, nonconfrontational protest policing is made possible through the state's articulation of legitimacy. Far from being natural to state practice, this articulation is learned through experiencing the repercussions of past protest repression, and imposed through the global discourse of rights.

The second observation is that the adoption of nonconfrontational protest policing may not be entirely a byproduct of existing democratic institutions. In the UK where minimal force strategy has influenced the state's response to street protest, paramilitary policing was introduced following the 1960s urban riots that invoked a threat to public order beyond the control of the police. Whereas the U.S. security forces opted for the negotiated management approach after the 1980s, the $9 / 11$ attacks set the scene for the return to militarized protest policing. These methodological inconsistencies reflect the other side of the coin of the legitimacy articulation by the state. The preservation of public order is not only top-down, but also bottom-up. In democracies, the government derives its legitimacy to rule from the popular will, and a part of this social contract is the government's provision of public security. When high-key threats, such as violent riots or "terrorist" attacks surge, electoral constituents may demand that the incumbent government take tougher security measures, including the use of force and surveillance, to the extent of suspending the right to freedom of speech. Street protests that emerge in this context of "democracy at war" are likely to encounter public legitimization of their suppression by the government (see Rossiter 2002; Agamben 2005; Mann 2005). Here, too, the state and its apparatus articulate the scale of legitimacy. Failure to remove a national threat associated with a protest movement may cause a crisis of legitimacy. Resorting to the use of force and inventing technologies for controlling demonstrations are seen as politically necessary. In this sense, a protest movement is not faced with repression from above, but from below; that is, the popular support for a forceful approach to protest policing.

\section{Conclusion}

This article has argued that the articulation of legitimacy by the state and its apparatus should be taken into consideration in the analysis of state response to demonstrations. The survey of existing literature regarding development of protest policing practices in the United States and the UK brings to the 
fore methodological oscillation between armed and unarmed responses. To understand this dynamic, I have proposed that despite the relevance of institutional factors, the politics of legitimacy underpinning a democratic polity accounts for decisions by governments and police forces about how to handle grievance groups taking to the streets. When protests are seen as legitimate, forceful responses potentially undermine the credibility of a government and the police. However, in the backdrop of precarious national security, a government may derive from the general public the legitimacy to eliminate threats to public order, including street protests. Democracies are not immune to this tendency, as discussed in this paper. Amidst this backdrop, a critical challenge for protest movements for social change is not only to "fight" the powers that be, but also to win the public mind.

\section{References}

Agamben, Giorgio. 2005. The State of Exception. Chicago: University of Chicago Press.

Amnesty International. 2008. "USA-Stun Weapons in Law Enforcement." http://www. amnesty.org/en/library/info/AMR51/129/2008/en (accessed March 22, 2015).

Amnesty International. 2012. "USA: Stricter Limits Urged as Deaths Following Police Taser Use Reach 500.” February 15. https://www.amnesty.org/en/articles/news/2012/02/ usa-stricter-limits-urged-deaths-following-police-taser-use-reach/ (accessed March 22, 2015).

Arendt, Hannah. 1970. On Violence. London \& New York: Harcourt Inc.

Bond, Doug. 1994. "Nonviolent Action and the Diffusion of Power." In Justice without Violence, eds. Paul Wehr, Heidi Burgess, and Guy Burgess. Boulder \& London: Lynne Rienner Publishers, 59-80.

Chenoweth, Erica, and Maria J. Stephan. 2011. Why Civil Resistance Works: The Strategic Logic of Nonviolent Conflict. New York: Columbia University Press,

Churchill, Ward, and Jim Vander. 1990. Agents of Repression: The FBI's Secret Wars against the Black Panther Party and the American Indian Movement. Boston: South End Press.

Cromwell, Paul, and Robert Lewis. 1971. "Crowds, Mobs, and Riots: A Sociological Analysis." Police 16 (1): 30-32.

Davenport, Christian. 2005. "Introduction: Repression and Mobilization: Insights from Political Science and Sociology." In Repression and Mobilization, eds. Christian Davenport, Carol Mueller, and Hank Johnston. Minneapolis: University of Minnesota Press, vii-xx.

de La Boétie, Étienne. [1552] 1975. The Politics of Obedience: The Discourse of Voluntary Servitude. Translation by Harry Kurz. New York: Free Life Editions.

della Porta, Donatella. 1996. "Social Movements and the State: Thoughts on the Policing of Protest." In Comparative Perspectives on Social Movements, eds. Douglas McAdam, John D. McCarthy, and Mayer N. Zald. Cambridge: Cambridge University Press, 6292.

della Porta, Donatella. 2013. Can Democracy be Saved? Cambridge: Polity. 
della Porta, Donatella and Herbert Reiter, eds. 1998. Policing Protest: The Control of Mass Demonstrations in Western Democracies. Minneapolis: University of Minnesota Press. della Porta, Donatella, and Herbert Reiter. 1998. "Introduction: The Policing of Protest in Western Democracies.” In della Porta and Reiter 1998, 1-34.

della Porta, Donnatella, and Herbert Reiter. 2006. “The Policing of Transnational Protest: A Conclusion.” In The Policing of Transnational Protest, eds. Donnatella della Porta and Herbert Reiter. Hampshire: Ashgate, 175-190.

della Porta, Donatella, and Mario Diani. 1999. Social Movements: An Introduction. Oxford: Blackwell Publisher.

Donelly, Jack. 2009. "Ethics and International Affairs." In Ethics and International Human Rights, eds. Joel H. Rosenthal and Christian Barry. Tokyo: United Nations University Press.

Dragnich, Alix. 1972. “Crowd Control Training in Nassau County." Law and Order 20 (5): 24-35.

Earl, Jennifer. 2003. “Tanks, Tear, Gas, and Taxes: Toward a Theory of Movement Repression.” Sociological Theory 2 (1): 44-68.

Elias, Norbert. 2000. The Civilizing Process. Massachusetts: Blackwell Publishers.

Ellison, Graham and Greg Martin. 2000. "Policing, Collective Action and Social Movement Theory: the Case of the Northern Ireland Civil Rights Campaigns." British Journal of Sociology 51 (4): 681-699.

Fernandez, Luis A. 2008. Policing Dissent: Social Control and the Anti-Globalization Movement. New Brunswick: Rutgers University Press.

Foucault, Michel. 1973. Madness and Civilization. Translated by Richard Howard. New York: Vintage/Random House.

Foucault, Michel. 1975. The Birth of the Clinic: An Archeology of Medical Perception. Translated by A. M. Sheridan. New York: Vintage/Random House.

Foucault, Michel. 1979. Discipline and Punishment: The Birth of the Prison. Translated by Alan Sheridan. New York: Vintage/Random House.

Foucault, Michel. 1990. The History of Sexuality. Translated by Robert Hurley. London: Penguin Books.

Gobinet, Pierre. 2011. "Procurement and Policy: Police Use of Emerging Weapons Technology.” In Small Arms Survey 2011: States of Security. Cambridge: Cambridge University Press.

Gora, Joel M., David Goldberger, Gary M. Stern, and Morton H. Halperin. 1991. The Right to Protest: The Basic ACLU Guide to Free Expression. Carbondale: Southern Illinois.

Hobsbawm, Eric John. 1959. The Primitive Rebels: Studies in Archaic Forms of Social Movement in the 19th and 20th Centuries. Manchester: Manchester University Press.

INCLO (International Network of Civil Liberties Organizations). 2013. "Take Back the Streets: Repression and Criminalization of Protest around the World.” October. https://www.aclu.org/files/assets/global_protest_suppression_report_inclo.pdf (accessed March 22, 2015).

Janjira Sombatpoonsiri. 2013. "If You Use Nonviolence, I will Respond with Nonviolence: A Nonviolent Conflict in the Case of the 2007 Pattani Protest, Southern Thailand." In Conflict Transformation: Essays on Methods of Nonviolence, eds. Rhea DuMont, Tom Hastings, and Emiko Noma. NC: McFarland, 52-65.

Janjira Sombatpoonsiri. 2014. “Towards Nonviolent Protest Policing and Its Legitimacy of 
Proximity, Thailand's 2013-14 Protests." Paper presented at the International Peace Research Association, August 10-15, Istanbul.

Jefferson, Tony. 1987. "Beyond Paramilitarism." British Journal of Criminology 27 (1): 4753.

Jefferson, Tony. 1990. The Case against Paramilitary Policing. Milton Keynes: Open University Press.

Johansen, Anja. 2008. "Policing and Repression: Military Involvement in the Policing of French and German Industrial Disputes 1889-1914." European History Quarterly 34 (1): 69-98.

Kaldor, Mary. 1998. New and Old Wars: Organized Violence in a Global Era. Cambridge: Polity.

Kenny, John M., Clark McPhail, Peter Waddington, Sid Heal, Steve James, Donald N. Farrer, Jim Taylor, and Dick Odenthal. 2001. "Crowd Behavior, Crowd Control, and the Use of Non-Lethal Weapons: Human Effects Advisory Panel: Report of Findings." Pennsylvania: Institute for Non-Lethal Defense Technologies.

Khalek, Rania. 2011. "6 Creepy New Weapons the Police and Military Use to Subdue Unarmed People.” Alternet, August 1. http://www.alternet.org/story/151864/6_ creepy_new_weapons_the_police_and_military_use_to_subdue_unarmed_people (accessed March 22, 2015).

Kowalewski, David. 2003. "Vigilantism.” In International Handbook of Violence Research, eds. Wilhelm Heitmeyer and John Hagan. Dordrecht, Boston: Kluwer Academic Publishers, 339-349.

Kratcoski, Peter C. 2001. "Policing of Public Order: A World Perspective." Police Practice 2 (1-2): 109-43.

Le Bon, Gustav. [1895] 1960. The Crowd: A Study of the Popular Mind. New York: Viking Press.

Lohman, Joseph. 1947. The Police and Minority Groups. Chicago: Chicago Park District.

Looney, Francis. 1970. “The Human Factor in Crowd Control.” Law and Order 18 (5): 3482.

MacDonald, John M., Robert J. Kaminski, and Michael R. Smith. 2009. “The Effect of LessLethal Weapons on Injuries in Police Use-of-Force Events.” American Journal of Public Health 99 (12): 2268-2274.

Mackenzie, Ian, and Darryl Plecas. 2011. "Policing Public Order in Canada." In Public Order: A Global Perspective, eds. Dilip K. Das and Allan Y. Jiao. Upper Saddle River, NJ: Pearson Prentice Hall, 45-60.

Mann, Michael. 2005. The Dark Side of Democracy: Explaining Ethnic Cleansing. Cambridge: Cambridge University Press.

Marx, Gary T. 1979. "External Efforts to Damage or Facilitate Social Movements: Some Patterns, Explanations, Outcomes, and Complications." In The Dynamics of Social Movements: Resource Mobilization, Social Control and Tactics, eds. Mayer N. Zald and John D. McCarthy. Cambridge: Winthrop, 94-125.

McAdam, Douglas, John McCarthy, and Mayer Zald, eds. 1996. Comparative Perspectives on Social Movements: Political Opportunities, Mobilizing Structures, and Cultural Framing. Cambridge: Cambridge University Press.

McPhail, Clark, David Schweingruber, and John D. McCarthy. 1998. "Policing Protest in the United States: 1960-1995.” In della Porta and Reiter, 1998, 49-69. 
McPhail, Clark, and John D. McCarthy. 2005. "Protest Mobilization, Protest Repression, and Their Interaction." In Repression and Mobilization, eds. Christian Davenport, Carol Mueller, and Hank Johnston. Minneapolis: University of Minnesota Press, 3-32.

Mitchell, Don, and Lynn Staeheli. 2005. "Permitting Protest: Parsing the Fine Geography of Dissent in America." International Journal of Urban and Regional Research 29 (4): 796-813.

Momboisse, Raymond. 1967a. "The Problem of Crowds and Mobs." Police 11 (3): 80-89.

Momboisse, Raymond. 1967b. "Manpower and Command in Riots." Police 12 (1): 34-40.

Momboisse, Raymond. 1967c. "Demonstrations and Civil Disobedience." Police 12 (2): 7682.

Momboisse, Raymond. 1967d. Riots, Revolts and Insurrections. Springfield, IL: Charles C. Thomas Publisher.

Nepstad, Sharon Erickson. 2011. Nonviolent Revolutions: Civil Resistance in the Late 20th Century. Oxford: Oxford University Press.

Nocella, Anthony J. and David Gabbard. 2013. Policing the Campus: Academic Repression, Surveillance, and the Occupy Movement. New York: Peter Lang Publishing Inc.

Parton, Heather Digby. 2011. "Militarizing the Police: How the Drug War and 9/11 Led to Battle-Dressed Cops Cracking Down on Peaceful Protests." Alternet, November 14. http://www.alternet.org/story/153062/militarizing_the_police\%3A_how_the_drug war_and_9_11_led_to_battle-dressed_cops_cracking_down_on_peaceful_protests (accessed March 22, 2015).

Pegg, Charles. 1968. "Comments on Riots and Mobs." Law and Order 16 (5): 48-104.

Pinker, Steven. 2011. The Better Angels of Our Nature: Why Violence Has Declined. New York: Viking.

Redekop, Vern Neufeld, and Shirley Fare. 2010. Beyond Control: A Mutual Respect Approach to Protest Crowd-Police Relations. London: Bloombury Academic.

Reiner, Robert. 1998. "Policing, Protest, and Disorder in Britain." In della Porta and Reiter 1998, 35-48.

Rosanvallon, Pierre. 2011. Democratic Legitimacy: Impartiality, Reflexivity, Proximity, trans. Arthur Goldhammer. Oxford \& Princeton, Princeton University Press.

Rossiter, Clinton. 2002. Constitutional Dictatorship: Crisis Government in the Modern Democracies. Princeton: Princeton University Press.

Schock, Kurt. 2005. Unarmed Insurrections: People Power Movements in Nondemocracies. Minneapolis and London: University of Minnesota Press.

Schweingruber, David. 2000. "Mob Sociology and Escalated Force: Sociology's Contribution in Repressive Police Tactics." The Sociological Quarterly 41 (3): 374-389.

Sharp, Gene. 1973. The Politics of Nonviolent Action. Boston, MA: Porter Sargent.

Sherr, Avro. 1989. Freedom of Protest: Public Order \& the Law. Oxford and New York: Basil Blackwell.

Sluka, Jeffrey A., ed. 2000. Death Squad: The Anthropology of State Terror. Pennsylvania: University of Pennsylvania Press.

Small Arms Survey. 2011. "Less Lethal Weapons." Research Notes: Weapons and Markets, July. http://www.smallarmssurvey.org/fileadmin/docs/H-Research_Notes/SASResearch-Note-8.pdf (accessed March 22, 2015).

Stevenson, John. 1977. "Social Control and the Prevention of Riots in England 1789-1829." In Social Control in 19th Century Britain, ed. A. P. Donajgrodski. London: Cross 
Helm, 27-50.

Storch, Robert. 1980. "Crime and Justice in 19th Century England." History Today 30: 3236.

Swain, Val. 2013. "Disruption Policing: Surveillance and the Right to Protest." Open Security, August 8. http://www.opendemocracy.net/opensecurity/val-swain/ disruption-policing-surveillance-and-right-to-protest (accessed March 22, 2015).

Tilly, Charles. 1978. From Mobilization to Revolution. New York: Random House.

Tyler, Tom R. 2004. "Enhancing Police Legitimacy." Annals of the American Academy of Political and Social Science 593 (May): 84-99.

Vitale, Alex S. 2005. "From Negotiated Management to Command and Control: How the New York Police Department Polices Protests." Policing and Society: An International Journal of Research and Policy 15 (3): 283-304.

Waddington, P.A.J. 1987. “Towards Paramilitarism? Dilemmas in Policing Civil Disorder." British Journal of Criminalogy 27 (1): 37-46.

Waddington, P.A.J. 1991. The Strong Arm of the Law: Armed and Public Order Police. Oxford: Clarendon Press.

Waddington, P.A.J. 1994. Liberty and Order: Public Order Policing in a Capital City. London: University College London (UCL).

Waddington, P.A.J. 1998. "Controlling Protest in Contemporary Historical and Comparative Perspective." In della Porta and Reiter 1998, 117-142.

Weber, Max. 2002. "Politics as a Vocation." In Violence: A Reader, ed. Catherine Besterman. New York: New York University Press, 13-18.

Wolf, Naomi. 2012. "Revealed: How the FBI Coordinated the Crackdown on Occupy." The Guardian, December 29. http://www.theguardian.com/commentisfree/2012/dec/29/ fbi-coordinated-crackdown-occupy (accessed March 22, 2015).

Zunes, Stephen, Sarah Beth Asher, and Lester Kurtz, eds. 1999. Nonviolent Social Movements: A Geographical Perspective. New Jersey: Wiley-Blackwell.

Janjira Sombatpoonsiri is Lecturer in International Relations, and Peace and Conflict Studies at Thammasat University. She holds a doctorate in Politics and International Relations from Melbourne's La Trobe University. She also serves as co-Secretary General of the Asia-Pacific Peace Research Association. Her book Humor and Nonviolent Struggle in Serbia is forthcoming from Syracuse University Press. The present article is a constitutive part of a research project funded by the Thailand Research Fund (TRF). E-mail: jsombutpoonsiri@gmail.com 
